\title{
Urban Living Lab as a Circular Economy Ecosystem: Advancing Environmental Sustainability through Economic Value, Material, and Knowledge Flows
}

\author{
Anil Engez ${ }^{1, *(\mathbb{D})}$, Seppo Leminen ${ }^{2,3,4}$ (D) and Leena Aarikka-Stenroos ${ }^{1(D)}$ \\ 1 Center for Innovation and Technology Research, Unit of Industrial Engineering and Management, Faculty of \\ Management and Business, Tampere University, FI-33720 Tampere, Finland; leena.aarikka-stenroos@tuni.fi \\ 2 Department of Business, Strategy and Political Sciences, University of South-Eastern Norway, \\ N-3007 Drammen, Norway; seppo.leminen@usn.no \\ 3 School of Business, Department of Marketing, Aalto University, FI-00076 Aalto, Finland \\ 4 Sprott School of Business, Carleton University, Ottawa, ON K1S 5B6, Canada \\ * Correspondence: anil.engez@tuni.fi
}

Citation: Engez, A.; Leminen, S.; Aarikka-Stenroos, L. Urban Living Lab as a Circular Economy

Ecosystem: Advancing

Environmental Sustainability through Economic Value, Material, and Knowledge Flows. Sustainability 2021, 13, 2811. https://doi.org/ 10.3390/su13052811

Academic Editor: Fabio Carlucci

Received: 21 January 2021

Accepted: 28 February 2021

Published: 5 March 2021

Publisher's Note: MDPI stays neutral with regard to jurisdictional claims in published maps and institutional affiliations.

Copyright: (C) 2021 by the authors Licensee MDPI, Basel, Switzerland. This article is an open access article distributed under the terms and conditions of the Creative Commons Attribution (CC BY) license (https:/ / creativecommons.org/licenses/by/ $4.0 /)$.

\begin{abstract}
Environmental sustainability is an increasingly relevant aspect of urban living labs. The objective of this study is to examine an urban living lab through ecosystem approach lenses and reveal the actor activities and diverse flows between them, enabling sustainable urban development. The study examines an urban area through four living lab projects in the Hiedanranta district in Tampere in Finland. We apply a qualitative research design strategy including semi-structured interviews reinforced with the project reports and websites. The collaboration and co-creation nature of living labs resembles an ecosystem structure, as both include diverse complementary actors and have distinctive coordination mechanisms, shared goals, and system-level outcomes. Building on the ecosystem analogy and circular economy ecosystem typology, our study examines living labs as ecosystems, enabling the economic value flow, material flow, and knowledge flow and pursuing the shared goal of improved environmental sustainability. The findings of the study demonstrate how the different ecosystem types manifest in urban living labs, and the actors, flows, and outcomes in these ecosystems. The study concludes that urban sustainability-oriented living labs comprise all main types of circular economy ecosystems. The dominant type of the activities (biased to economic value, material, or knowledge) determines the ecosystem type in an urban living lab, highlighting a key topic for future research: The contribution of collaborative projects to environmental sustainability in urban living labs realized through diverse ecosystem types.
\end{abstract}

Keywords: living lab; urban living lab; circular economy; sustainability; ecosystem; resource efficiency; nutrient recycling

\section{Introduction}

The interest in and significance of environmental sustainability has been growing globally due to the increased awareness of the effects of climate change on natural habitats [1]. Such global developments draw attention to the need for more resource-efficient and regenerative systems, which can be experimented with and tested in a living lab environment $[2,3]$.

Living labs are one of the most recent forms of open innovation networks, providing multiple research opportunities $[4,5]$. Living labs scrutinize multiple disciplines and concepts such as the transition to low-carbon economies, experimental governance, and new approaches to sustainable development [6,7]. A living lab emphasizes the roles of user involvement, prototyping, testing, and validating in the creation of new technologies, services, products, or systems in real-life settings [8]. Living labs adopt an experimentation approach and involve public-private-people partnerships in the co-creation process [9]. 
Living labs are distinguished from other open-innovation approaches by allowing users to improve the technologies that are being co-created and tested with other stakeholders in real-life environments [10]. A living lab consists of a physical region or virtual realities where the actual collaboration among stakeholders takes place [4].

This paper particularly examines urban living labs for environmental sustainability and circular economy. An urban living lab is a living lab formed in an urban area [2], including different stakeholders such as companies, researchers, authorities, users, and residents who develop solutions for existing problems in an urban area. The use of the living lab concept for the development of urban areas enables rapid social, technical, and economic transformation [6]. In the context of urban living labs, city districts that are under development are seen as innovation spaces where new applications are tested on a large scale [11]. Urban living labs are increasingly applied for environmental sustainability and circular economy, and they aim to regenerate neighborhoods, support circular companies, enable tenders for circular experimentation, and allow decentralized waste recovery systems to be tested [12]. Acknowledging [13,14], we define circular economy as a restorative and generative economic system, which aims to maintain the value of products, materials, and resources by reducing, reusing, recycling, and recovering materials in production/distribution and consumption processes. As the term sustainability includes the pillars of economic, environmental, and social development and refers to maintaining performances of these three pillars over time, circular economy concept contributes to sustainability with an emphasis on the economic and environmental benefits [15].

In this paper, we argue that an urban living lab for environmental sustainability and circular economy can be considered as a multi-actor ecosystem: The ecosystem conceptualization has been applied increasingly during the last decade [16] to refer to diverse complex multi-actor settings. An ecosystem conceptualization can be considered both as a theoretical concept (e.g., business ecosystem; innovation ecosystem) and more loosely, as a metaphor referring to a broad system of multiple actors. The collaboration and co-creation processes in living labs resemble the ecosystems, as both have distinctive coordination mechanisms, shared goals, system-level outcomes, and network conceptualizations [17]. Acknowledging Aarikka-Stenroos et al. [18] and Thomas and Autio [17], this study applies the ecosystem concept, referring to a heterogeneous community, a system of actors that are hierarchically independent and have diverse roles and a system-level goal or outcome. In this paper, we examine sustainable urban living labs as particular circular economy ecosystems [18]. Such ecosystems focus on resource circularity, circular economy knowledge, or circular economy business and business models as their shared goal and system-level outcome. The value network of an urban living lab ecosystem generates value through dynamic exchanges between various stakeholders, and these exchanges can be mapped as different value flows [19,20].

The extant urban living lab literature focuses on the sustainable urban living lab projects [2], the networked nature of living labs [21], the governance of the urban sustainability transitions [22], and the diversity of living labs and their actors [10,11]. However, studies on urban living labs as ecosystems focusing on environmental sustainability are nascent. Therefore, the objective of this study is to analyze ecosystem types in an urban living lab and their actors, flows, and outcomes regarding environmental sustainability. Our research questions are twofold:

- What are the circular economy ecosystem types in urban living labs?

- What are the actors, flows, and outcomes in urban living labs as urban circular economy ecosystems, contributing to environmental sustainability?

In this study, we generate a new understanding on urban living labs as we study how they function as a circular economy ecosystem: Collaborations in urban living labs, often actualized via projects, create an ecosystem in which the actors work towards the particular goal of the ecosystem (such as material flow). Actors' collaborations in a particular project often concern the same topic (such as nutrient recycling). Thus, an urban living lab contains several parallel ecosystems, in which multiple projects take place. In the identified urban 
living lab ecosystems, the dominant type of the project activities determines the ecosystem type that a project belongs to. The project activities include knowledge flows, material flows, and economic value flows, which result in the description of the corresponding ecosystem type in the urban living lab. We integrate the ecosystem approach into sustainability and circularity [18], as our study complements this conceptual discussion by providing an empirical in-depth analysis of circular economy ecosystems actualized in living lab settings. Our study showcases how diverse actors from companies, the city, universities, and users/residents and flows in sustainable urban living labs constitute circular economy ecosystems.

This paper is structured as follows. Following this introduction, we discuss the actors in urban living labs and the circular economy ecosystems to elaborate on the current understanding. In the third section, we present the research design of the study. In the fourth section, we present the circular economy ecosystem types in the Hiedanranta urban living lab and the results of the study. The fifth section concludes the paper and synthesizes the results, which includes the theoretical contribution, practical implications, and the limitations and future research topics respectively.

\section{Urban Living Labs for Environmental Sustainability and Circular Economy}

\subsection{Actors and Activities in Urban Living Labs}

Urban living labs comprise various actors that take part in the practice-based innovation activities in an urban area, tackling varying urban challenges. These actors are categorized mainly as municipalities, companies, research institutes, and residents [11]. Another approach to classifying the living lab actors points out the actors' roles and goals of participating in the living lab and uses the following categorizations, respectively: Enablers, utilizers, providers, and users, which is in line with the action-based role theory $[9,10]$. Action-based role theory explains the actor roles through their actions: An actor takes a role to achieve a specific goal. The roles act as a means to organize innovation in networks, and to assess the resource and partner selection when conducting the tasks that are associated with the roles [10]. Therefore, to some extent, the roles describe the contribution and commitment of the actors to specific goals in the urban living lab.

The enabling characteristics of municipalities indicate the supportive nature of the public sector actors and their role in creating a vision and spreading and communicating the vision to other actors in the urban living lab. This "enables" the emergence of innovations for urban challenges. The companies in urban living labs improve their knowledge capital through collaborations while continuing the development of their business operations in the area, which demonstrates the utilization of collaborations for the company's benefit. Therefore, one of the motives for a company to participate in an urban living lab is to gain a competitive advantage through information retrieval from other actors, especially users [9]. The research institutes and universities bring up the methods, tools, expertise, and additional resources that they offer for the development. The long-term research projects conducted in the urban living labs make it possible to generate reliable knowledge. Lastly, residents, as the essential actors of the urban living labs, use and test the solutions that are developed and provide their feedback for further improvements [11,23]. Although each actor type is introduced with specific roles, these roles might change over time as they are context-specific and depend on the innovation network's needs and goals [10,24].

\subsubsection{Municipalities}

Cities are innovation spaces and areas for urban living labs where various opportunities can emerge that accelerate sustainability and environmental transitions [25]. The experiments that take place in cities can be scaled up to generate broad systemic change [26], and municipalities, as enablers, are the prominent actors in the local sustainability governance [22]. Municipalities adopt the experimental governance approach in urban living labs, which emphasizes knowledge generation and innovation development through open and engaged learning [6]. Municipalities are embedded in local networks, partnerships, 
and collaborations, and seek the expertise of public and private actors to implement local policies [27].

\subsubsection{Residents}

As one of the crucial actors of open-innovation in urban contexts, residents as users have the potential to influence the decision making in urban governance and positively affect the urban development and their living environments [28]. Residents play a direct role in designing and developing innovations to address sustainability challenges [22]. Including residents already in the early design stage of the urban living labs helps identify the user needs that would shape the development process [29]. In some cases, the residents in urban living labs are not necessarily involved as users. The solutions that are developed might not have a use for a resident, but instead may serve the resident, as in the case of nature-based solutions that are developed to manage the stormwater for flood prevention [30].

\subsubsection{Companies}

Companies in an urban living lab drive the transition to a low-carbon economy and sustainable living by engaging in the development of innovative solutions [6]. Some of the solutions that enable sustainable living include renewable energy production; urban farming; the utilization of nutrient, energy, and material flows; and the utilization of side streams from the production activities. By undertaking these tasks, companies tackle various urban issues such as poor air and water quality or waste disposal problems. The primary goals of companies in urban living labs include economic performance improvements while reducing the environmental impact of their operations [6]. Developing and testing products and services with other actors are the additional motives for companies to take part in urban living labs. While performing these activities, companies utilize the user data that are easily accessible due to the open-innovation approach that the urban living labs adopt, which provides open and engaged learning [24]. Companies seek agile actions and rapid results in living labs to apply strategies according to their business goals. Although urban living labs mainly serve the objectives of municipalities, it is still beneficial for companies to participate in an urban living lab, in terms of making use of the information and knowledge created in a collaborative setting $[9,24]$. Moreover, tackling urban challenges with proven innovative products and services might be of use in the value proposition for business prospects.

\subsubsection{Research Organizations}

Urban living labs provide the opportunity for cross-disciplinary research, which enhance ties between the creators and users of the generated knowledge [6]. Urban living labs act as a basis for theory development, knowledge creation, and the discovery of new teaching and research methods, which can be argued to be the roles of the research organizations in urban living labs [9]. Research organizations are responsible for generating objective knowledge of scientific practice in urban living labs to influence policies. The outcome of the research activities might have the potential to influence urban development policies in areas of sustainable infrastructure design or material procurement strategies [25]. The researchers may act as consultants when opinions are needed on technical decisions such as the selection of monitoring equipment and its location [6]. Commercialization of the solutions as a result of the research projects can be sought to upscale the impact. However, the local knowledge production does not always find its way to creating a widespread impact, as there might be misalignment between scientists and policymakers due to the organizational differences [6,31]. One of the reasons for the misalignment is the lack of an established standard and protocol for data storage and incorporation of this data into decision-making processes. This holds important implications as science and policy are interconnected in urban sustainability [6]. 


\subsection{Circular Economy Ecosystems in Urban Living Labs}

In this paper, we examine urban living labs as circular economy ecosystems. Three flow types in circular economy ecosystems are identified, namely ecosystems that address economic value flow, material flow, and knowledge flow [18]. In this paper, we will examine how they are present in urban living labs. First, economic value flow-based ecosystems focus on the sustainable production of goods and services. This type of ecosystem typically consists of a central hub actor that coordinates other actors for the system-level outcome of a sustainable value proposition; in other words, here the ecosystem actors contribute to creating business and flow of money from diverse resources. Next, material flow-based ecosystems describe efficient resource flow and resource circularity in a regional system, in which recycling and reuse are the fundamental actions [32]. In this type of ecosystem, administrative actors and physical infrastructure play an important role. Material flow-based ecosystems enable the local resource flow through industrial or public-private collaborations; in brief, the actors can for example enable recycling of an important resource. Last, knowledge flow-based ecosystems reveal the transformation of the knowledge derived from research into sustainable products and services through the open processes of R\&D and innovation [33]. Here the actors jointly develop new knowledge on diverse circulating resources.

One archetype of circular economy ecosystem, namely urban circular economy ecosystems (such as urban living labs), supports urban amenities, promotes societal activities, develops and improves infrastructure, and produces goods and services [18]. The actors in such ecosystems take part in various projects that are in line with the goal of the ecosystem (to enable material flow, knowledge flow, or monetary/economic value flow). The projects in the ecosystems act as a vehicle for actors to pursue sustainable urban development [34]. Policy, governance, culture, and individual and collective behavior are the driving factors for determining the adoption levels of sustainability in urban ecosystems [35]. Figure 1 below illustrates how the projects and ecosystems are positioned in an urban living lab. An urban living lab consists of three types of ecosystem, and in each ecosystem, there are multiple ongoing projects.

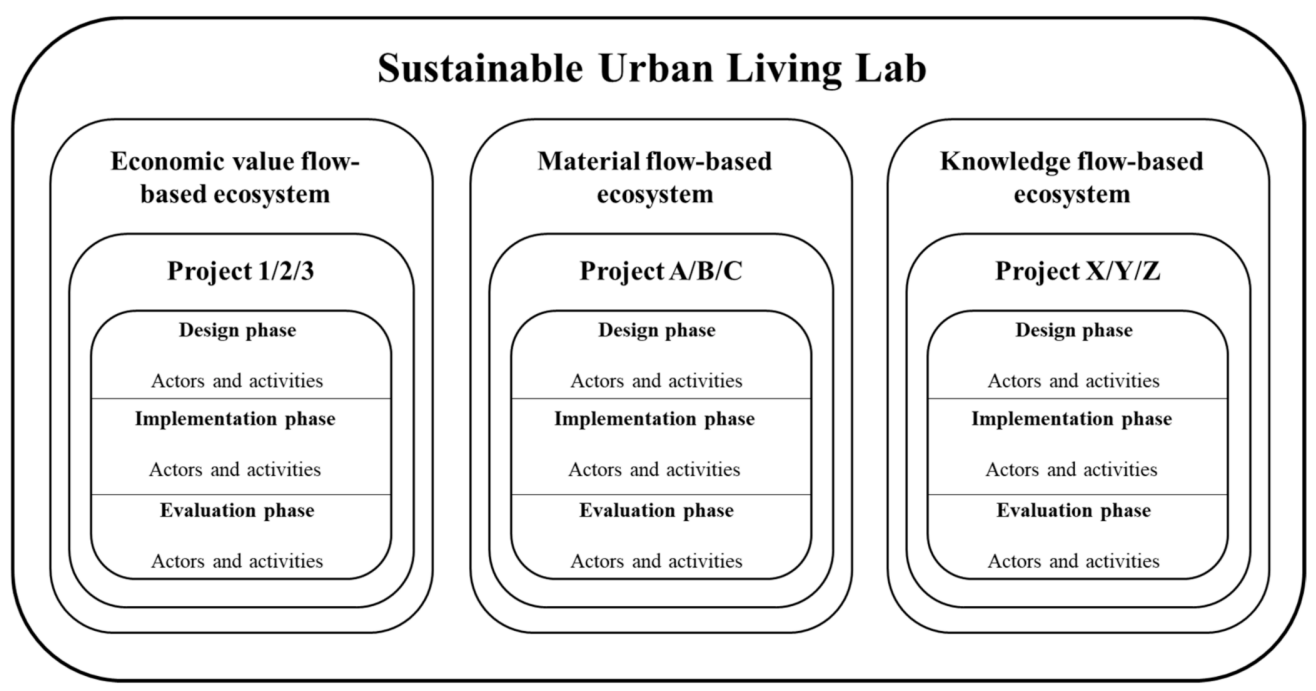

Figure 1. Sustainability-oriented urban living lab for improving economic value, material, and knowledge flows through projects.

\section{Research Design}

This study is a qualitative and explorative single case study in a developing city district, namely Hiedanranta urban living lab in Tampere, Finland. Hiedanranta is a work-in-progress lakeside urban district where 25,000 residents are expected to reside in the upcoming years. Along with its new residents, 10,000 new jobs will be created 
as part of the development activities in the area. The objective of the municipality is to build a smart and sustainable future city district in Hiedanranta that produces more resources than it consumes. Some of the development activities in Hiedanranta include utilizing smart technology in the infrastructure, planning of the transportation solutions, construction of the new residential buildings with the aim of improving the services and everyday life of residents. The city district experiments with circular economy by having a biochar production plant, vertical farming facility, dry toilets in the event venue, and an algae growing plant in the area. The urban area includes various research projects, business activities, and citizen participation in the development of the district. Thus, this purposefully selected area provides a strategic case to study sustainable urban living lab, its diverse actors, flows, and goals related to improving sustainability and circularity.

The case study is carried out in the period of January 2019-December 2020. It contains four projects (KIEPPI, NutriCity, Hierakka, and UNaLab) occurring in Hiedanranta district, which engage diverse actors to collaborate for circularity. The unit of analysis is the design, implementation, and evaluation phases of the projects along with the actors and activities in these phases. The projects concern specific sustainability and circularity related themes and goals (such as improving nutrient recycling) that require actors to collaborate for the economic value flow, material flow, or knowledge flow. We selected the projects based on their high impact on environmental sustainability. The case study is constructed based on extensive data from multiple sources, including nine semi-structured interviews conducted by the author, longitudinal observation, the websites of the companies and the municipality that provide information about the ongoing research projects in the district, and the project reports. We recorded and transcribed the interviews. We conducted interviews with the managers of the urban living lab firms, city development project managers from the municipality, and researchers who are involved in the projects that take place in the urban living lab. The key informants are selected based on their key responsibilities in the selected projects, companies, and the municipality, having an impact on the sustainable development of Hiedanranta. The details of the interviews are listed in Table 1 below.

Table 1. Interviews.

\begin{tabular}{|c|c|c|c|c|}
\hline Actor Type & Role & Theme & Date & Duration \\
\hline Municipality/Researcher & $\begin{array}{l}\text { Project Manager } \\
\text { (Urban } \\
\text { planning/Nutrient } \\
\text { recycling) }\end{array}$ & $\begin{array}{l}\text { Ongoing nutrient recycling projects } \\
\text { in the city associated with the } \\
\text { development of the region }\end{array}$ & 21 March 2019 & $45 \mathrm{~min}$ \\
\hline Municipality & $\begin{array}{l}\text { Project Manager } \\
\text { (Urban planning) }\end{array}$ & $\begin{array}{c}\text { Stakeholder engagement in the city } \\
\text { development }\end{array}$ & 12 April 2019 & $52 \mathrm{~min}$ \\
\hline Municipality & $\begin{array}{l}\text { Project Manager } \\
\text { (Urban planning) }\end{array}$ & $\begin{array}{l}\text { Ongoing development on the } \\
\text { partnership model for sustainable } \\
\text { neighborhoods }\end{array}$ & 2 April 2020 & $64 \mathrm{~min}$ \\
\hline Researcher & $\begin{array}{l}\text { Project Manager } \\
\text { (Nutrient recycling) }\end{array}$ & $\begin{array}{l}\text { Research on dry toilets and } \\
\text { utilization of nutrients from urine }\end{array}$ & 27 March 2019 & $55 \mathrm{~min}$ \\
\hline Researcher & $\begin{array}{c}\text { Project Manager } \\
\text { (Nutrient recycling) }\end{array}$ & $\begin{array}{l}\text { Research in microalgae plant and } \\
\text { using nutrients for microalgae } \\
\text { growth }\end{array}$ & 4 April 2019 & $25 \mathrm{~min}$ \\
\hline Company & General Manager & $\begin{array}{l}\text { Nutrient recycling activities in the } \\
\text { vertical farming facility in the area }\end{array}$ & 2 April 2019 & $53 \mathrm{~min}$ \\
\hline Company & General Manager & $\begin{array}{l}\text { Information about the biochar } \\
\text { company and its operations }\end{array}$ & 17 May 2018 & $44 \mathrm{~min}$ \\
\hline Company & General Manager & $\begin{array}{l}\text { Information about the dry toilet } \\
\text { company and its operations }\end{array}$ & 23 May 2018 & $23 \mathrm{~min}$ \\
\hline Association & Project Manager & $\begin{array}{l}\text { Benefits of dry toilets for nutrient } \\
\text { recycling and required policy and } \\
\text { infrastructure changes for their } \\
\text { adoption }\end{array}$ & 10 April 2019 & $60 \mathrm{~min}$ \\
\hline
\end{tabular}


At the analysis stage, the design, implementation, and evaluation phases of the projects, the driving actors in each phase, their activity sets, and the type of flows were identified. Data analysis phases are listed in Table 2 in more detail.

Table 2. Data analysis process.

\begin{tabular}{|c|c|c|}
\hline Data Analysis Phases & Task & Outcome \\
\hline 1. Open coding & $\begin{array}{l}\text { - Dataset organization } \\
\text { - Identifying the urban living lab projects } \\
\text { that focus on environmental sustainability } \\
\text { Identifying the informants from the projects } \\
\text { to be interviewed }\end{array}$ & $\begin{array}{c}\text { Overview of urban living lab projects and } \\
\text { the informants that are associated with } \\
\text { the projects }[10,36]\end{array}$ \\
\hline 2. Focused coding \#1 & $\begin{array}{l}\text { - Identifying the project phases } \\
\text { - Identifying the ecosystems that the projects } \\
\text { are involved in } \\
\text { - Identifying the involved actors in the } \\
\text { project phases }\end{array}$ & $\begin{array}{c}\text { Overview of project phases, the involved } \\
\text { actors in each phase, and the urban living } \\
\text { lab ecosystems [18] }\end{array}$ \\
\hline 3. Focused coding \#2 & $\begin{array}{l}\text { - Identifying the activity sets and the type of } \\
\text { flows in the design, implementation, and } \\
\text { evaluation phases of the projects }\end{array}$ & $\begin{array}{l}\text { Overview of the activity sets and the type } \\
\text { of flow that a specific activity belongs to }\end{array}$ \\
\hline 4. Theorizing the codes & $\begin{array}{l}\text { - Synthesizing phases } 1 \text { to 3: analyzing the } \\
\text { contribution of the projects to the urban } \\
\text { development and environmental } \\
\text { sustainability } \\
\text { Describing the actors, flows, and outcomes } \\
\text { in urban living lab ecosystems }\end{array}$ & $\begin{array}{l}\text { Conceptualization of the ecosystems in } \\
\text { urban living labs and their comparison } \\
\text { with the literature }\end{array}$ \\
\hline
\end{tabular}

\section{Ecosystem Types and Flows in Hiedanranta Urban Living Lab and Its Projects}

4.1. Economic Value Flow and Related Ecosystem in Urban Living Labs: Project on Developing a Partnership Model for Environmentally Sustainable Neighborhoods

We analyzed an economic value flow and related ecosystem in an urban living lab by examining the Kestävien Kaupunginosien Kumppanuusmalli (KIEPPI) project that aims to create a partnership model for sustainable neighborhoods in the three cities in Finland. Hiedanranta district in the city of Tampere is one of the focus areas in the project where the urban areas are increasingly redesigned according to sustainability and circular economy principles. Tampere municipality coordinated the project and the European Union funded it. The funding mechanism and the partnership model support the creation of carbon-neutral technologies, services, or innovations in cooperation with companies, research organizations, and municipalities. Apart from the solutions related to the utilization of waste and side streams, the municipality as the driving actor of the project seeks solutions for four identified themes: Premises and services for the circular economy, material circulation, urban food production, and the improvement of blue-green infrastructure in the city district to improve the wellbeing of future residents. In our analysis, we focus on the project activities that deal with the Hiedanranta development.

The municipality's inclusive efforts are in line with the experimental governance approach that the urban living labs adopt, as the municipality encourages action through partnerships and facilitates stakeholders to collaborate. According to the project manager, the municipality has never taken such a role in the development of a certain urban area before, which is Hiedanranta area in this case. The city currently faces many new challenges relating to urban planning, co-creation, and cooperation models for the Hiedanranta development. The municipality allocates resources to the sustainable development of Hiedanranta and maintains resources for this specific purpose. In order to accelerate the 
development and to make it more structured, the municipality has launched a company that works independently and manages the urban planning and construction of the infrastructure and park areas in Hiedanranta. The development company is solely responsible for the development of Hiedanranta. Therefore, the innovation activities in the Hiedanranta development depend highly on the external actors, and the city acts as a bureaucratic actor rather than an innovative actor. The project manager highlights that the external actors mainly consist of companies and research institutes, and that the citizen involvement in this project is minimal. The project focuses on reducing waste and increasing resource efficiency in industrial procurement and applications where the citizens do not have a major impact.

The municipality offers the Hiedanranta area to companies and research organizations to perform their activities and introduce novel ideas and solutions that would develop Hiedanranta as a self-sufficient city district. The anticipated involvement level is highest for the companies and lowest for the residents. It is underlined by the project manager that incentives, such as different types of subsidies or lower rents offered to companies and research organizations, might be needed to attract them to take part in Hiedanranta. In the case of infrastructure procurement, the municipality has a huge role in creating sustainable business opportunities, as it is one of the biggest buyers of infrastructure materials. If the municipality starts demanding more sustainable infrastructure services, the whole industry would have to change, which would enable a shift from linear business models to circular business models. Eventually, this might also lead to the emergence of companies that value the use of recycled or reused materials.

In the design phase of the project, the municipality identified three development themes. The City of Tampere partners with an expert consulting firm to develop the partnership model and to identify the methods that will be used to attract companies and research organizations to the area. The expert consulting firm has complete control over designing the partnership model. Once the model is created, three partner cities of the project will jointly utilize the model. Recently, the municipality initiated a tendering process to invite suppliers or contractors to conduct the pilot projects. The tender aims to attract startups since the budget for pilots is relatively low for large companies. However, larger companies might still have an interest in the pilots due to the anticipated growth in the city district area. The city uses the tendering process as a means to test out the companies' motivation to cooperate with the city and participate in the partnership model. One downside of the tendering process is that it only allows the companies that are based in Finland to submit an offer, which restricts the participation of interested innovators from other countries that might be capable of accomplishing the goal of the development of Hiedanranta. However, the project manager highlights that the main goal is the creation of the partnership model and discovery of the innovations and technologies rather than pilots per se. In the evaluation phase of the project, scaling up the results to the city level and exporting the partnership model to other cities as a concept will be pursued. Figure 2 below illustrates the project phases, driving actors, activity sets, and the activity flow types.

The goal of the project is not the pilots but the creation of the partnership model as it also shows in the budget. Pilots are there to test out the partnership model and to test out the businesses' cooperation with the city. Also, to discover what kind of innovations and technologies the companies already have at hand (Project manager of KIEPPI Tampere). 


\section{Project KIEPPI Tampere}

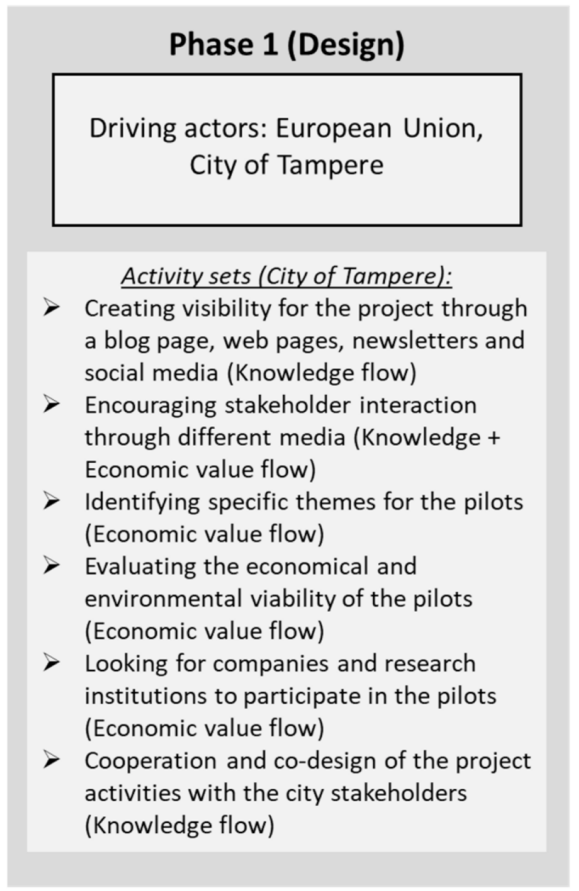

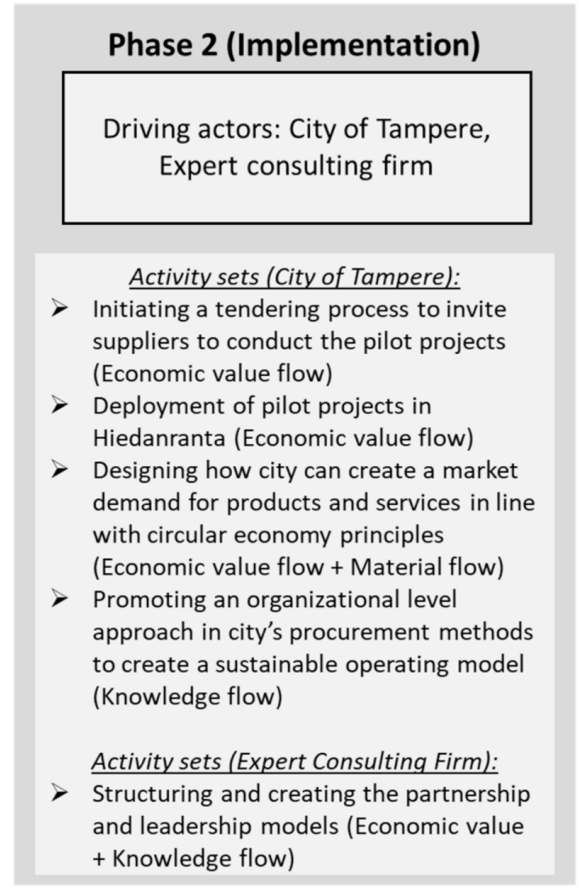

Figure 2. Driving actors and activity sets in Project Kestävien Kaupunginosien Kumppanuusmalli (KIEPPI) Tampere.

\subsection{Material Flow and Related Ecosystem in Urban Living Labs: Projects on Nutrient Recycling in Hiedanranta Urban Living Lab}

Next, we analyze the material flow and related ecosystems in an urban living lab by focusing on the relevant material flows, namely nutrients. The Hiedanranta district aims to be a carbon-neutral and sustainable urban area where nutrient recycling is crucial. In line with this goal, several projects have been initiated in the area in cooperation with research organizations and companies, which are discussed next. The projects have a top-down approach as there is a push from the European Union and the Ministry of the Environment in Finland to enhance nutrient recycling for the improvement of the environment and water bodies.

NutriCity project aims to reduce the amount of nutrient leakage into the Baltic Sea by recycling human waste nutrients through alternative sanitation solutions such as dry and vacuum toilet systems. The Ministry of the Environment of Finland funded the project, and the City of Tampere implemented it together with Tampere University of Applied Sciences (TAMK) and The Finnish Environment Institute (SYKE). The goal of the project is to recover nutrients such as phosphorus and nitrogen from the human waste fractions through dehydration and produce fertilizers. Based on the results of the NutriCity project, an operating model for resource and energy-efficient management and utilization of nutrients containing wastewater fractions in cities will be created. The project manager of NutriCity represents the municipality and university and has a dual role in the project as she is part of both organizations, therefore bringing the technical knowledge into the municipality. According to the project manager, in Tampere, there is a strong cluster of research in the use of alternative sanitation systems such as dry and vacuum toilets. The same actors from the cluster are usually involved in the projects associated with nutrient recycling. The project manager points out that although there is pressure from authorities to recycle nutrients for more sustainable food production, major players in the food industry in Finland are unwilling to use grains that are produced with fertilizers made from wastewater sludge due to the risks of contaminants. Therefore, in practice, the low acceptance of the fertilizers made from recycled nutrients is a bottleneck in their market creation. This brings up the 
question of whether authorities, companies, and researchers should come up with new strategies and solutions that would make such products accepted while ensuring that there are no risks to health and the environment. In all the nutrient recycling projects, the municipality offers the event venue Kuivaamo to be used for research purposes. The dry toilet systems in the event venue that were implemented by the dry toilet company make it possible to collect urine for conducting studies on its properties and suitability for use as fertilizers. The dry toilet company acts as an equipment supplier in the area. In the project, residents have both the roles of informant and tester, as they can test the dry toilets located in Hiedanranta and provide their feedback through an online survey that seeks resident opinions on utilizing alternative toilet solutions for urban nutrient cycles.

There is a top-down pressure from the European Union and the Ministry of Environment of Finland to enhance nutrient recycling, and there's also funding for that from those resources. Cities are consumption hubs, there are lots of nutrients concentrated here (Project manager of NutriCity).

Another nutrient recycling project, Hierakka (Promoting nutrient cycle and participatory communication in Hiedanranta), was a one year-project that started in 2017 and ended in 2018. The Ministry of the Environment of Finland funded the project and the City of Tampere implemented it together with Tampere University of Applied Sciences. The study determined the properties of separately collected urine, such as nutrient and harmful metal concentrations, drug and contaminant residues, and microbiological quality. The study also investigated the possible effects of urine fertilizers on the soil's physical properties such as acidity and organic matter content. The results of the study acted as a means to convince authorities, the food industry, and farmers of the functionality of urine as a fertilizer and to change the attitude towards the use of urine fertilizers. The project focused on similar issues as the NutriCity project and used the same resources such as dry toilets in Hiedanranta and the funding source. The urine collected from the Hiedanranta dry toilets was tested as fertilizer in agricultural fields and in the vertical farming company located in Hiedanranta. The company offered its premises to the researchers for testing the effectiveness of the urine fertilizers on crops. In the project, local farmers had the tester role who tested urine fertilizers and saw their positive effect after harvesting in the late phase of the growing season. Figure 3 below illustrates the project phases, driving actors, activity sets, and the activity flow types.

\section{Nutrient Recycling Projects (NutriCity, Hierakka)}

\begin{tabular}{|c|c|c|}
\hline Phase 1 (Design) & Phase 2 (Implementation) & Phase 3 (Evaluation) \\
\hline $\begin{array}{c}\text { Driving actors: City of Tampere, } \\
\text { Ministry of the Environment of } \\
\text { Finland }\end{array}$ & $\begin{array}{l}\text { Driving actors: SYKE, Tampere } \\
\text { University, TAMK, City of Tampere, } \\
\text { Farmers, Residents, Equipment } \\
\text { supplier company }\end{array}$ & $\begin{array}{c}\text { Driving actors: City of Tampere, } \\
\text { TAMK }\end{array}$ \\
\hline $\begin{aligned} & \text { Activity sets (City of Tampere): } \\
& \text { Creating visibility for the project through } \\
& \text { information platforms (e.g. page in } \\
& \text { municipality's website) (Knowledge flow) } \\
&>\quad \text { Conducting surveys to see the resident } \\
& \text { opinions on utilizing alternative toilet } \\
& \text { solutions for urban nutrient cycles } \\
& \text { (Knowledge flow) } \\
&>\text { Installing dry and vacuum toilet systems }\end{aligned}$ & $\begin{array}{c}\text { Activity sets } \\
\text { (SYKE, Tampere University, TAMK): } \\
\text { Conducting urine and black water } \\
\text { treatment experiments using advanced } \\
\text { methods (Material flow + Knowledge } \\
\text { flow) } \\
>\text { Monitoring the quality of crops that } \\
\text { were grown using urine fertilizers }\end{array}$ & $\begin{array}{l}\text { Activity sets (City of Tampere, TAMK): } \\
\text { Creating an operating model for } \\
\text { resource and energy-efficient } \\
\text { management and utilization of nutrient - } \\
\text { containing wastewater fractions in cities } \\
\text { (Material flow + Economic flow) } \\
>\text { Changing the attitude towards the use of } \\
\text { urine fertilizers (Material flow }+ \\
\text { Knowledge flow) }\end{array}$ \\
\hline $\begin{array}{l}\text { in Hiedanranta to be tested (Material } \\
\text { flow) }\end{array}$ & $\begin{aligned} \text { Carrying out environmental impact and } \\
\text { lifecycle assessments (Material flow) } \\
\text { Assessing the system's capacity on } \\
\text { handling the processing of huge } \\
\text { amounts of nutrient fractions } \\
\text { (Knowledge flow + Material flow) }\end{aligned}$ & \\
\hline
\end{tabular}

Figure 3. Driving actors and activity sets in nutrient recycling projects. 
In some very populous countries, there are no phosphorous reserves. These countries are solely dependent on imported phosphorous. So, to feed people in the future, every means of recycling is important, if we think of it in a broader manner. In the urine separation and in these methods of nutrient recovery from different media, we are not talking about today's situation, but we consider how things will be in 50 years or 100 years. That's where I think it's a necessity, to recover all the sources possible (Project manager of Hierakka).

\subsection{Knowledge Flow and Related Ecosystem in Urban Living Labs: Project on Developing Nature-Based Solutions}

Last, we analyze a knowledge flow and related ecosystem in an urban living lab setting by outlining the collaborative setting for knowledge creation, particularly in nature-based solutions. Climate change induces the need for such solutions in urban areas as it will affect the Nordics by bringing more rain. Since the greenfield lands in cities are diminishing due to the newly built roads and houses because of densifying population, there is a risk of a reduction in the water infiltration capacity and loss of biodiversity. These issues emphasize the importance of nature-based solutions in urban areas. UNaLab is a European Union-funded project that aims to implement nature-based solutions to tackle climate- and water-related challenges in the urban areas of three frontrunner cities: Tampere, Eindhoven, and Genoa. Tampere, as one of the frontrunner cities in the project, has two locations for the implementation of the pilots, which are the city districts of Hiedanranta and Vuores. The objectives of the project are to develop the monitoring and impact of nature-based solutions, to develop business models around the nature-based solutions, and to engage people to co-create multi-functional nature-based solutions that work as parks and recreational areas for the residents. In our analysis, we will investigate the pilots in these two city districts where UnaLab Tampere deals with the water issues as part of the nature-based solutions.

The project has the same manager as the NutriCity project, who represents the City of Tampere in the activities and events organized by the UNaLab consortium. The consortium consists of 28 partners from 10 cities, including municipalities, research organizations, and businesses. One of the solutions implemented in the Hiedanranta area is the biofilter for the contaminated waters caused by the nearby old pulp landfill. The system has been designed together with experts and the residents of the surrounding areas. The biochar company in Hiedanranta acted as a material provider by supplying the biochar to be used as biofilter. The projects in Vuores work as a benchmark for the Hiedanranta development. In the other city district, Vuores central, a hybrid stormwater management system (medium-sized retention pond) was built to retain and purify the stormwater. Automatic measurements monitor water quality and flow throughout the year. The residents acted as an informant, tester, and designer in the project and shared their need for easy accessibility to forests and walking paths. The residents also took part in the design workshops and contributed to the ideation process together with the city officials. The project used innovation vouchers to build a horse paddock and community gardens in apartment buildings to attract more people to develop solutions together with the city. Figure 4 below illustrates the project phases, driving actors, activity sets, and the activity flow types.

We have a stormwater sewage network that is leading directly from the streets to lakes without treatment. And there is flooding in few spots of the city. And now the new thinking is that we should increase green areas instead of leading all the waters to the pipes, we should increase the multifunctional blue-green infrastructure in the city, like parks where there are streams that can hold the stormwater. The co-creation in living labs has to be well thought in terms of what is the contribution of citizens, how do we take people to co-create these things with us, and how the co-creation can be honest and fruitful (Project manager of UNaLab Tampere). 


\section{Project UNaLab Tampere}

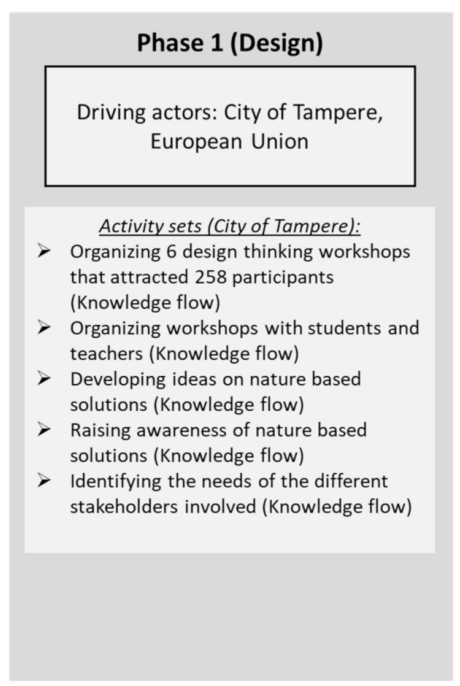

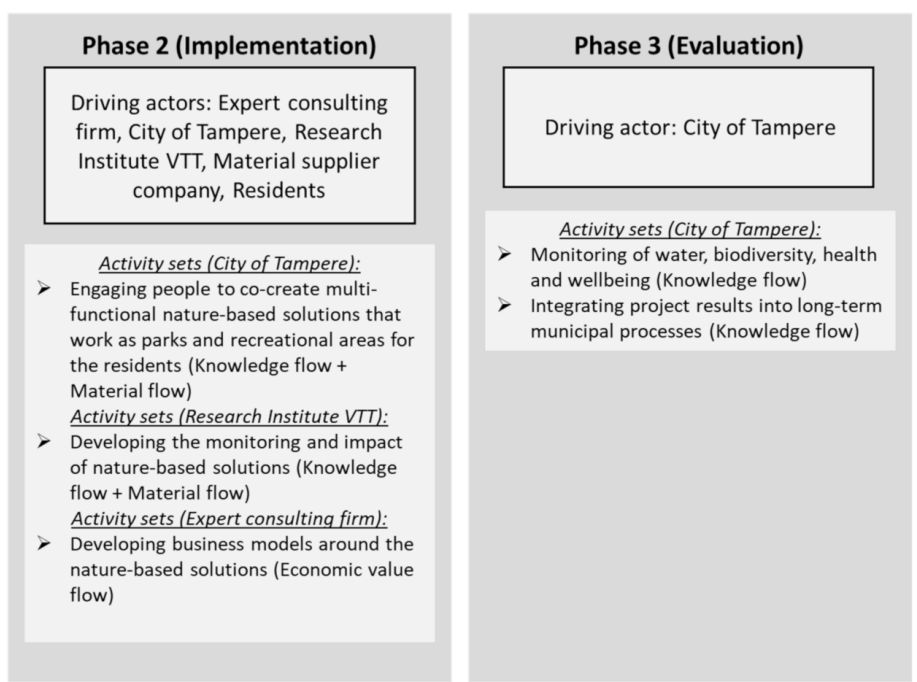

Figure 4. Driving actors and activity sets in Project UNaLab Tampere.

\subsection{Summing Up and Discussing the Results}

Our case study analyzed sustainable urban living labs as circular economy ecosystems and examined relevant ecosystem actors and their activities around the flows of materials, knowledge and economic value, and outcomes of these ecosystems regarding environmental sustainability. Our analysis leads to multiple key findings.

First, our study shows how the sustainable urban living labs promote knowledge, material, and economic value flows between actors and how they advance sustainable practices in the city district. Our case study in Hiedanranta showcases how economic value, material flow, and knowledge flow-based ecosystems occur in an urban living lab for sustainability. The economic value flow-based ecosystem includes companies that perform carbon-neutral business activities, which results in sustainable products. The municipality provides resources for companies that have material circulation and sharing practices for waste utilization. Therefore, in economic value-flow based ecosystems in urban living labs, the municipality seemed to act as a coordinator to bring together the companies that promote the economic-value flow.

Material-flow based ecosystems inherently recover nutrients from biowaste or household waste fractions that have the potential to be utilized as fertilizers. The material-flow aspect emphasizes the circulation of the materials that can be recycled, such as the cycle of the household waste being converted to fertilizers. In this type of ecosystem, research institutes and universities facilitated the experiments for circulating the materials.

The knowledge flow-based ecosystem develops nature-based solutions with the inclusion of residents and preserves nature by purifying the stormwater that might otherwise contaminate the water bodies, thus contributing to the environmental sustainability of the urban area while benefiting from resident participation and feedback. The knowledge flows among the residents, researchers, and the municipality to develop the stormwater management systems through participant feedback. In all three ecosystems, the municipality promotes the sustainability mentality in all activities. Table 3 lists the actors, flows, and outcomes in ecosystems in the Hiedanranta urban living lab. 
Table 3. The actors, flows, and outcomes in ecosystems in Hiedanranta urban living lab.

\begin{tabular}{|c|c|c|c|}
\hline & $\begin{array}{c}\text { Economic Value Flow-Based } \\
\text { Ecosystem (Example: } \\
\text { KIEPPI) }\end{array}$ & $\begin{array}{l}\text { Material Flow-Based Ecosystem } \\
\text { (Example: Nutrient Recycling Projects) }\end{array}$ & $\begin{array}{c}\text { Knowledge Flow-Based } \\
\text { Ecosystem (Example: } \\
\text { UnaLab) }\end{array}$ \\
\hline Actors & $\begin{array}{ll}- & \text { European Union } \\
- & \text { Municipality } \\
- & \text { Companies } \\
\text { - } & \text { Consulting firm }\end{array}$ & $\begin{array}{ll}- & \text { Municipality } \\
- & \text { Ministry of the Environment } \\
- & \text { Research institutes and universities } \\
- & \text { Farmers } \\
- & \text { Residents } \\
- & \text { Equipment suppliers }\end{array}$ & $\begin{array}{ll}- & \text { European Union } \\
- & \text { Municipality } \\
- & \text { Companies } \\
- & \text { Consulting firm } \\
- & \text { Research institute } \\
- & \text { Residents } \\
- & \text { Material suppliers }\end{array}$ \\
\hline Flows & 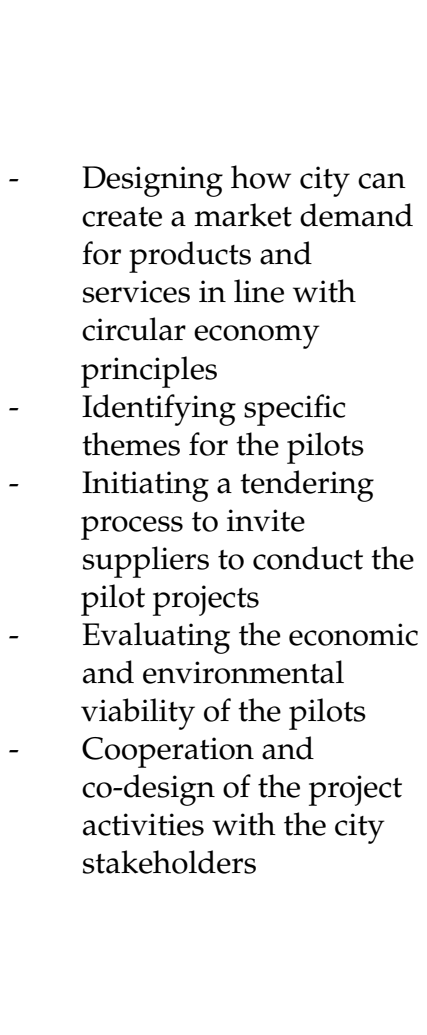 & 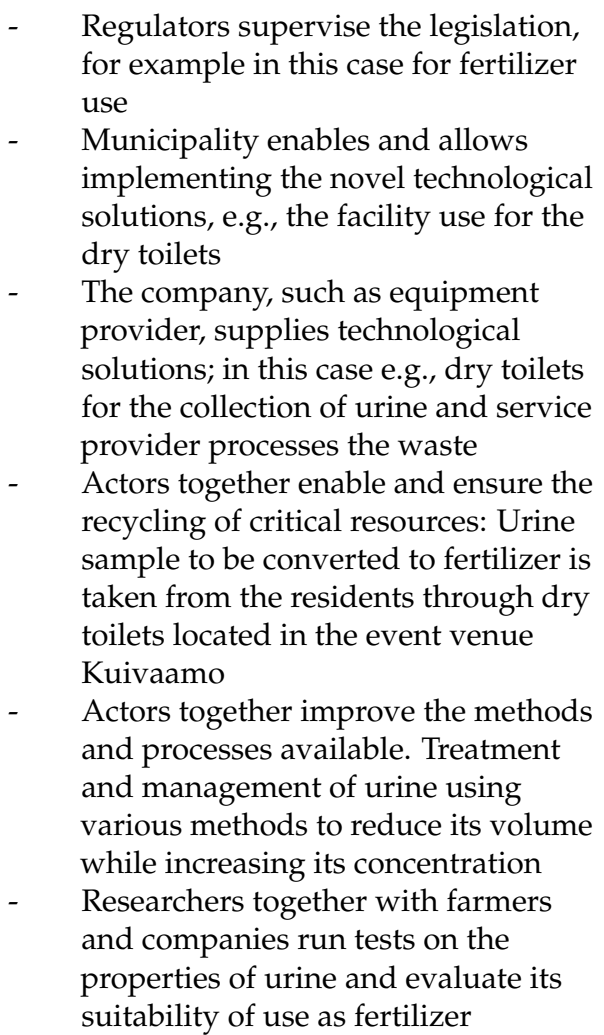 & 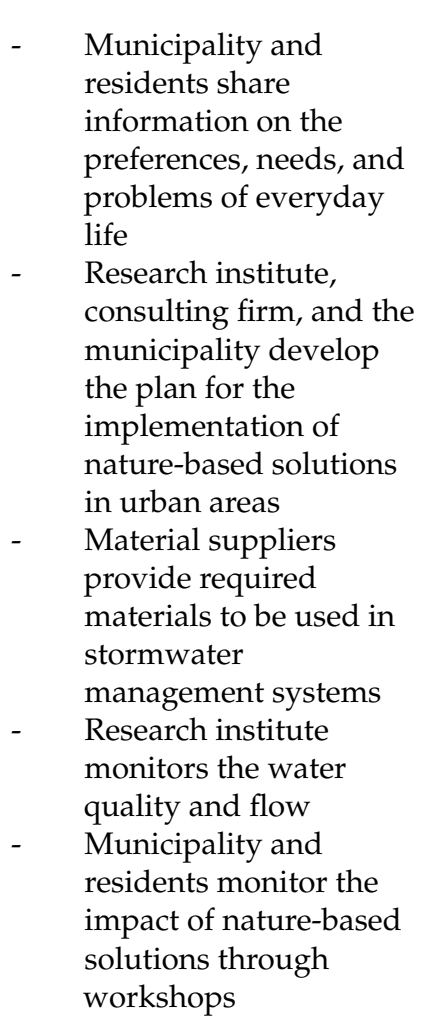 \\
\hline
\end{tabular}

Improving the economic value and business from the

Outcomes location-specific resource in a sustainable way, e.g., creating a partnership model for sustainable neighborhoods

Ecosystem goals
Sustainable production and flow of economic value

Improving circularity of important resources in the location, e.g., recycling nutrients from wastewater and residential waste

Efficient resource flow and resource circularity in a regional system
Creating and disseminating new knowledge and solutions for sustainable environment, e.g., developing nature-based solutions such as stormwater management systems

Transformation of the knowledge derived from research into sustainable products and services

Second, the number of research projects, the number of active companies in the living lab, their size and scope, and the municipality's open mindset to try novel applications in the city district play a major role when determining the impact and level of contribution of a certain actor type to the development and sustainability of an urban living lab.

Third, in urban living lab ecosystems realized through projects, the driving actors may change in the project development phases depending on the required tasks and the competence and expertise level of the set of actors. When reflecting on the ecosystem 
approach, the finding underlines that actors setting and actors' role in urban living lab ecosystems are rather dynamic. In all the projects examined in the study, the municipality facilitates the development by engaging other actors such as technical experts, companies, residents, and researchers. This indicates a strong involvement of the municipality in the local sustainability governance: thus, it holds a strong role in the ecosystems for circularity in local environments. As our case demonstrated, Hiedanranta urban living lab and involved actors pursue similar objectives as other European urban living labs [12], which are regenerating neighborhoods, supporting circular companies, enabling tenders for circular experimentation, and allowing decentralized waste recovery systems to be tested.

\section{Conclusions}

\subsection{Theoretical Contributions and Practical Implications}

Our key results stemming from the empirical in-depth case study on sustainable urban living labs as circular economy ecosystems generated multiple contributions. First, this study contributes to the urban living lab literature by discussing and analyzing the urban living labs as diverse ecosystem structures in the development of a sustainable city district. It showcases how living lab contributors as ecosystem actors collaborate around diverse flows of economic value, knowledge, and material resources, sharing the system-level goals, and thereby aiming to improve environmental sustainability as a collective action. Their diverse activities and activity sets demonstrate how they have complementary and dynamic roles in reaching such a shared goal. To put this differently, this study generated a new understanding of how urban living labs function as a circular economy ecosystem.

Our study reveals that urban living lab projects under the same theme (such as nutrient recycling) create an ecosystem in which the actors work towards the particular goal of the ecosystem (such as material flow) that is aligned with its theme. Thus, an urban living lab contains several ecosystems in which multiple projects take place to serve the goal of that particular ecosystem. Thus, our study extends the literature of living labs that have discussed ecosystems [37] as well as their knowledge, competencies, and materials within boundaries of living labs [38], but as far as we know, has not yet documented the multiplicity of ecosystems actively and simultaneously, or their flows in a single living lab(s).

Secondly, this study continues the emerging analysis of diverse multi-actor collaborations for circular economy and sustainability [18]. This empirical case study depicted and validated how the three major ecosystem types (ecosystems for economic value, knowledge, and material flow) may occur in urban living labs, often in parallel. Living labs have suggested generating and enhancing diverse outcomes [38]. Given that different ecosystem types and flows exist simultaneously, a living lab possesses and fosters diverse types of outcomes in each ecosystem.

Our third contribution is that our results build a bridge between living lab and ecosystem approaches. Both concepts include and engage multiple, diverse, complementary actors working towards a shared goal. Thus, we argue that living labs serve as platforms that nurture and foster the emergence and development of multi-actor ecosystems, engage diverse stakeholders and actors into collaboration, and thereby, bring together diverse needs of and contributions by different stakeholders. Our empirical study allows us to propose that sustainable urban living labs as platforms enable collaborations around flows and tie together the diverse actors and their interlinked actions towards their own and system level, shared goals. As suggested by [25], this study seeks further conceptualizations of the essence of living labs by implementing ecosystem and related flows as novel theoretical lenses.

Further, we identified that same actors act simultaneously in different ecosystems (e.g., companies can contribute not only to the flow of economic value but also to material and knowledge flow). Such findings expand the findings by [10], who suggested that stakeholders may have multiple roles in living labs. This study suggests that living labs 
and particularly living lab platforms make the diversity of ecosystems visible. They foster collaboration in and between ecosystems. Therefore, urban living labs for sustainability are a fruitful context for researchers examining material, knowledge, and economic value ecosystems that exist in parallel.

This study also develops several practical implications. First, we believe that our study can guide urban living labs development in practice as it demonstrates how ecosystem approach provides new lenses to consider collaborations, actor diversity as well as individual and system level goals, and thereby provides also new aspects to living lab management. Therefore, we encourage experts developing sustainable living labs to consider these aspects (e.g., displayed in Table 3), when initiating and managing collaborations for sustainable urban living labs. Second, to achieve favorable results in city development projects, the dwellers of a city district who practice sustainable living, businesses that contribute to circular economy, research organizations, and municipalities as governing bodies are suggested to collaborate and cooperate. As the initiator of the urban living lab, municipalities are encouraged to attract businesses and create new jobs based on the ideology of the circular economy. Third, the needs of the inhabitants of the district should be considered while testing and co-creating with them, and the sustainability aspect should be emphasized. For a city district that is planned to be carbon-neutral, it is crucial to note that in the process of urban growth, the flow of materials should circulate as closed and resource-efficient as possible. Fourth, a living lab platform provides the opportunity for small-scale testing of the circulating resources (such as nutrient recycling in this case) with the cooperation of municipalities, researchers, users, and companies. In order to increase the sustainability of a living lab, pilots can be run where one company's side stream can be the raw material and resource of another.

\subsection{Limitations and Future Research Topics}

This study focused on one urban living lab in a Nordic country, including multiple parallel projects, revealing the diversity of ecosystems in an urban living lab. As our focus of analysis was limited to durations of such projects in a single living lab, a more longitudinal analysis may widen our understanding of analyzing urban living labs. Acknowledging that living lab literature is scarce in longitudinal analysis of living labs [24], we suggest that further research could longitudinally analyze living labs crossing ecosystems. Our study suggests a diversity of flows in ecosystems as a glue that couples living labs and their underlying ecosystems. Further analysis of the roles for the development of living lab in ecosystems or the roles for the development of ecosystems in living lab would shed light on their concepts. Third, technological advance drives and limits the development of sustainable circular processes in urban living labs; thereby, future studies could focus even more on the role(s) of stakeholders to overcome such limits of circular process development. Finally, our study suggests further studies and conceptualizations of the identified flows in urban living labs and particularly of how such flows support innovation activities and/or outcomes of living labs and their ecosystems.

Author Contributions: Conceptualization, A.E., S.L. and L.A.-S.; methodology, A.E., S.L. and L.A.-S.; validation, A.E., S.L. and L.A.-S.; formal analysis, A.E., S.L. and L.A.-S.; investigation, A.E.; resources, A.E.; data curation, A.E.; writing-original draft preparation, A.E.; writing-review and editing, A.E., S.L. and L.A.-S.; visualization, A.E.; supervision, S.L. and L.A.-S. All authors have read and agreed to the published version of the manuscript.

Funding: This research was funded by Strategic Research Council, Academy of Finland, through the project entitled "Circular Economy Catalysts: From Innovation to Business Ecosystems" (CICAT2025) (grant ID 320194); the Academy of Finland, through the project entitled "Profi4-Urban Platform for the Circular Economy" (UPCE) (grant ID 318940); and the research grant that is awarded to Anil Engez by the Jenny and Antti Wihuri Foundation.

Institutional Review Board Statement: Ethical review and approval were waived for this study, due to the fact that the study did not require ethical approval. 
Informed Consent Statement: Informed consent was obtained from all subjects involved in the study.

Data Availability Statement: Publicly available datasets were analyzed in this study. This data can be found here: [https://www.tampere.fi/en/housing-and-environment/city-planning/developmentprograms/hiedanranta/innovative-hiedanranta.html]. The interview data presented in this study are available on request from the corresponding author. The data are not publicly available due to privacy.

Acknowledgments: An earlier version of the study was presented in the 31st ISPIM Conference: Innovating in Times of Crisis, Virtual Event. Seppo Leminen warmly acknowledges the funding of a Drammen City Municipality for his chaired professorship of Innovation and Entrepreneurship, which enabled his part in the article.

Conflicts of Interest: The authors declare no conflict of interest. The funders had no role in the design of the study; in the collection, analyses, or interpretation of data; in the writing of the manuscript, or in the decision to publish the results.

\section{References}

1. Kılkış, S. Sustainable development of energy, water and environment systems index for Southeast European cities. J. Clean. Prod. 2016, 130, 222-234. [CrossRef]

2. Voytenko, Y.; McCormick, K.; Evans, J.; Schliwa, G. Urban living labs for sustainability and low carbon cities in Europe: Towards a research agenda. J. Clean. Prod. 2016, 123, 45-54. [CrossRef]

3. Puerari, E.; de Koning, J.I.J.C.; von Wirth, T.; Karré, P.M.; Mulder, I.J.; Loorbach, D.A. Co-creation dynamics in Urban Living Labs. Sustainability 2018, 10, 1893. [CrossRef]

4. Hossain, M.; Leminen, S.; Westerlund, M. A systematic review of living lab literature. J. Clean. Prod. 2019, 213, 976-988. [CrossRef]

5. Leminen, S.; Westerlund, M. Living labs: From scattered initiatives to a global movement. Creat. Innov. Manag. 2019, 28, 250-264. [CrossRef]

6. Evans, J.; Karvonen, A. “Give Me a Laboratory and I Will Lower Your Carbon Footprint!”-Urban Laboratories and the Governance of Low-Carbon Futures. Int. J. Urban Reg. Res. 2014, 38, 413-430. [CrossRef]

7. Greve, K.; Leminen, S.; De Vita, R.; Westerlund, M. Unveiling the Diversity of Scholarly Debate on Living Labs: A Bibliometric Approach. Int. J. Innov. Manag. 2020. [CrossRef]

8. Engels, F.; Wentland, A.; Pfotenhauer, S.M. Testing future societies? Developing a framework for test beds and living labs as instruments of innovation governance. Res. Policy 2019, 48, 103826. [CrossRef]

9. Leminen, S.; Westerlund, M.; Nyström, A. Living Labs as Open-Innovation Networks. Technol. Innov. Manag. Rev. 2012, 2, 6-11. [CrossRef]

10. Nyström, A.G.; Leminen, S.; Westerlund, M.; Kortelainen, M. Actor roles and role patterns influencing innovation in living labs. Ind. Mark. Manag. 2014, 43, 483-495. [CrossRef]

11. Juujärvi, S.; Pesso, K. Actor Roles in an Urban Living Lab: What can we learn from Suurpelto, Finland? Technol. Innov. Manag. Rev. 2013, 3, 22-27. [CrossRef]

12. Cuomo, F.; Ravazzi, S.; Savini, F.; Bertolini, L. Transformative urban living labs: Towards a circular economy in Amsterdam and Turin. Sustainability 2020, 12, 7651. [CrossRef]

13. Kirchherr, J.; Reike, D.; Hekkert, M. Conceptualizing the circular economy: An analysis of 114 definitions. Resour. Conserv. Recycl. 2017, 127, 221-232. [CrossRef]

14. Ranta, V.; Aarikka-Stenroos, L.; Ritala, P.; Mäkinen, S.J. Exploring institutional drivers and barriers of the circular economy: A cross-regional comparison of China, the US, and Europe. Resour. Conserv. Recycl. 2018, 135, 70-82. [CrossRef]

15. Geissdoerfer, M.; Savaget, P.; Bocken, N.M.P.; Hultink, E.J. The Circular Economy-A new sustainability paradigm? J. Clean. Prod. 2017, 143, 757-768. [CrossRef]

16. Aarikka-Stenroos, L.; Ritala, P. Network management in the era of ecosystems: Systematic review and management framework. Ind. Mark. Manag. 2017, 67, 23-36. [CrossRef]

17. Thomas, L.D.W.; Autio, E. Innovation Ecosystems in Management: An Organizing Typology. In Oxford Research Encyclopedia of Business and Management; Oxford University Press: Oxford, UK, 2020.

18. Aarikka-Stenroos, L.; Ritala, P.; Thomas, L. Circular Economy Ecosystems: A Typology, Definitions, and Implications. In Research Handbook of Sustainability Agency; Teerikangas, S., Onkila, T., Koistinen, K., Mäkelä, M., Eds.; Edward Elgar: London, UK, 2021.

19. Allee, V. Reconfiguring the value network. J. Bus. Strategy 2000, 21, 36-39. [CrossRef]

20. Westerlund, M.; Leminen, S.; Rajahonka, M. Designing Business Models for the Internet of Things. Technol. Innov. Manag. Rev. 2014, 7, 5-14. [CrossRef]

21. Leminen, S.; Nyström, A.-G.; Westerlund, M.; Kortelainen, M.J. The effect of network structure on radical innovation in living labs. J. Bus. Ind. Mark. 2016, 31, 743-757. [CrossRef] 
22. Bulkeley, H.; Coenen, L.; Frantzeskaki, N.; Hartmann, C.; Kronsell, A.; Mai, L.; Marvin, S.; McCormick, K.; van Steenbergen, F.; Voytenko Palgan, Y. Urban living labs: Governing urban sustainability transitions. Curr. Opin. Environ. Sustain. 2016, $22,13-17$. [CrossRef]

23. Van Geenhuizen, M. Applying an RRI filter in key learning on urban living labs' performance. Sustainability 2019, 11, 3833. [CrossRef]

24. Leminen, S.; Nyström, A.G.; Westerlund, M. Change processes in open innovation networks-Exploring living labs. Ind. Mark. Manag. 2019, 91, 701-718. [CrossRef]

25. Leminen, S.; Rajahonka, M.; Westerlund, M. Towards Third-Generation Living Lab Networks in Cities. Technol. Innov. Manag. Rev. 2017, 7, 21-35. [CrossRef]

26. Geels, F.W. The multi-level perspective on sustainability transitions: Responses to seven criticisms. Environ. Innov. Soc. Transit. 2011, 1, 24-40. [CrossRef]

27. Kronsell, A.; Mukhtar-Landgren, D. Experimental governance: The role of municipalities in urban living labs. Eur. Plan. Stud. 2018, 26, 988-1007. [CrossRef]

28. Menny, M.; Voytenko Palgan, Y.; McCormick, K. Urban living labs and the role of users in co-creation. GAIA Ecol. Perspect. Sci. Soc. 2018, 27, 68-77. [CrossRef]

29. Bergvall-Kareborn, B.; Stahlbrost, A. Living Lab: An open and citizen-centric approach for innovation. Int. J. Innov. Reg. Dev. 2009, 1, 356-370. [CrossRef]

30. Chronéer, D.; Ståhlbröst, A.; Habibipour, A. Urban Living Labs: Towards an Integrated Understanding of their Key Components. Technol. Innov. Manag. Rev. 2019, 9, 50-62. [CrossRef]

31. Ingstrup, M.B.; Aarikka-Stenroos, L.; Adlin, N. When institutional logics meet: Alignment and misalignment in collaboration between academia and practitioners. Ind. Mark. Manag. 2020, 92, 267-276. [CrossRef]

32. Korhonen, J. Four ecosystem principles for an industrial ecosystem. J. Clean. Prod. 2001, 9, 253-259. [CrossRef]

33. Chesbrough, H. Managing Open Innovation. Res. Manag. 2004, 47, 23-26. [CrossRef]

34. Keeys, L.A.; Huemann, M. Project benefits co-creation: Shaping sustainable development benefits. Int. J. Proj. Manag. 2017, 35, 1196-1212. [CrossRef]

35. Bonato, D.; Orsini, R. Urban Circular Economy: The New Frontier for European Cities' Sustainable Development. In Sustainable Cities and Communities Design Handbook; Elsevier: Amsterdam, The Netherlands, 2018; pp. 235-245.

36. Leminen, S.; Westerlund, M. Cities as Labs: Towards Collaborative Innovation in Cities. Orch. Reg. Innov. Ecosyst. Espoo Innov. Gard. 2015, 167-175.

37. Shin, D. A living lab as socio-technical ecosystem: Evaluating the Korean living lab of internet of things. Gov. Inf. Q. 2019, 36, 264-275. [CrossRef]

38. Leminen, S.; Westerlund, M. Towards innovation in Living Labs networks. Int. J. Prod. Dev. 2012, 17, 43-59. [CrossRef] 